\title{
CHANGES BROUGHT BY THE INTERNET TO THE BUSINESS RELATIONSHIPS
}

\author{
Elena-Iulia Varga ${ }^{49}$ \\ https://doi.org/10.31410/itema.2018.106
}

\begin{abstract}
The informational society is the result of the most spectacular environment changes, following the key role information plays in the society. Within it, the main forces that modify the activity landscape of an organization, raises ambitious challenges to the personnel and determines them to adopt more flexible structures, were synthesize in contemporaneous studies [1]-[2] as being the digitalisation of the information, connectivity, globalization, the extraordinary progress of technology, the appearance of new types of intermediaries and the personalization of the market offers, of the messages and of the companies means of communication. Therefore in order to better understand the online business and the ecommerce concept we must also understand how Internet changed the way business is made. The Internet made possible the environment changes of the businesses that are today no longer restrained by the borders between countries (making worldwide growth for businesses possible), opening new communications paths, new ways of collaboration and coordination between consumers, traders and business partners. All this changes resulted in reconsidering older practices or adopting them to the new conditions or even more the creation of new practices. This is how new terms and concepts appeared: business got a new prefix becoming $\boldsymbol{e}$-business, while commerce migrated towards $\boldsymbol{e}$-commerce.
\end{abstract}

Keywords: Internet, e-business, e-commerce, business changes

\section{INTRODUCTION}

7 echnology evolution constantly influences the way communication is made: this is simple, instant and accessible to more and more people.

The $\boldsymbol{e}$-business term (electronic business) is a generic expression, first mentioned by IBM in 1990, which was used to define the use of Internet technologies for the improvement and the transformation of the business key processes. It is very important to understand that online business is not limited to only selling products through Internet. Electronic business also means staying in contact with the suppliers, with the possible business partners, with the clients but also promoting the companies' products and/or services using electronic means [3].

E-commerce (electronic commerce) is a particular electronic activity notion and can be defined as being the purchase and the selling of products and/or services using electronic means. The electronic commerce activity is currently one of the most dynamic net-economy developing areas. Internet allows not only to copy the classical ways of making commerce, but also perfecting them.

\footnotetext{
${ }^{49}$ University of Medicine, Pharmacy, Sciences and Technology of Targu Mures, 38 Gheorghe Marinescu Street, Tîrgu Mureș, 540139, ROMANIA
} 
While at the beginning electronic commerce only offered remote and online purchase services, once the Internet was widely used, new domains developed like: electronic procurement (eprocurement), online shops (e-shop, e-store, e-mall), virtual markets (marketspace), online auctions (e-auction), information brokerage, banking services (internet banking) or online stock exchange trading.

The most dynamic part remains the purchase of online goods and services.

\section{CHANGES OF THE ORGANIZATION ITSELF}

What concerns a company, the extraordinary progress of the computer and telecommunication technology determined key changes of its activities, not only just at client or business partner level but also with the world around it.

In an e-business there are three primary processes that are being improved:

1. Production processes, that include purchase, orders and stock resupply; processing payments; electronic links with the suppliers and the control of production processes;

2. Client oriented processes, that include promoting and marketing efforts, selling through Internet, processing of clients purchase and payment orders, but also the client support services;

3. Internal affair processes that include employee related services, training, internal information exchange, video-conferences and recruiting. Electronic apps improve the flow of information between production and selling that determines selling productivity improvement. Also, communication within working groups and the company electronic information transmission is made more efficient.

According to a study dedicated to the EU labour market, published by Eurostat, the percentage of employed persons aged 15 to 64 who usually work from home stood at $5.0 \%$ in 2017 . This figure was highest in the Netherlands (13.7\%), followed by Luxembourg (12.7\%) and Finland $(12.3 \%)$, and lowest in Bulgaria $(0.3 \%)$ and Romania (0.4\%). Working from home was slightly more common in the euro area (5.7\% of employed persons) than in the EU as a whole.

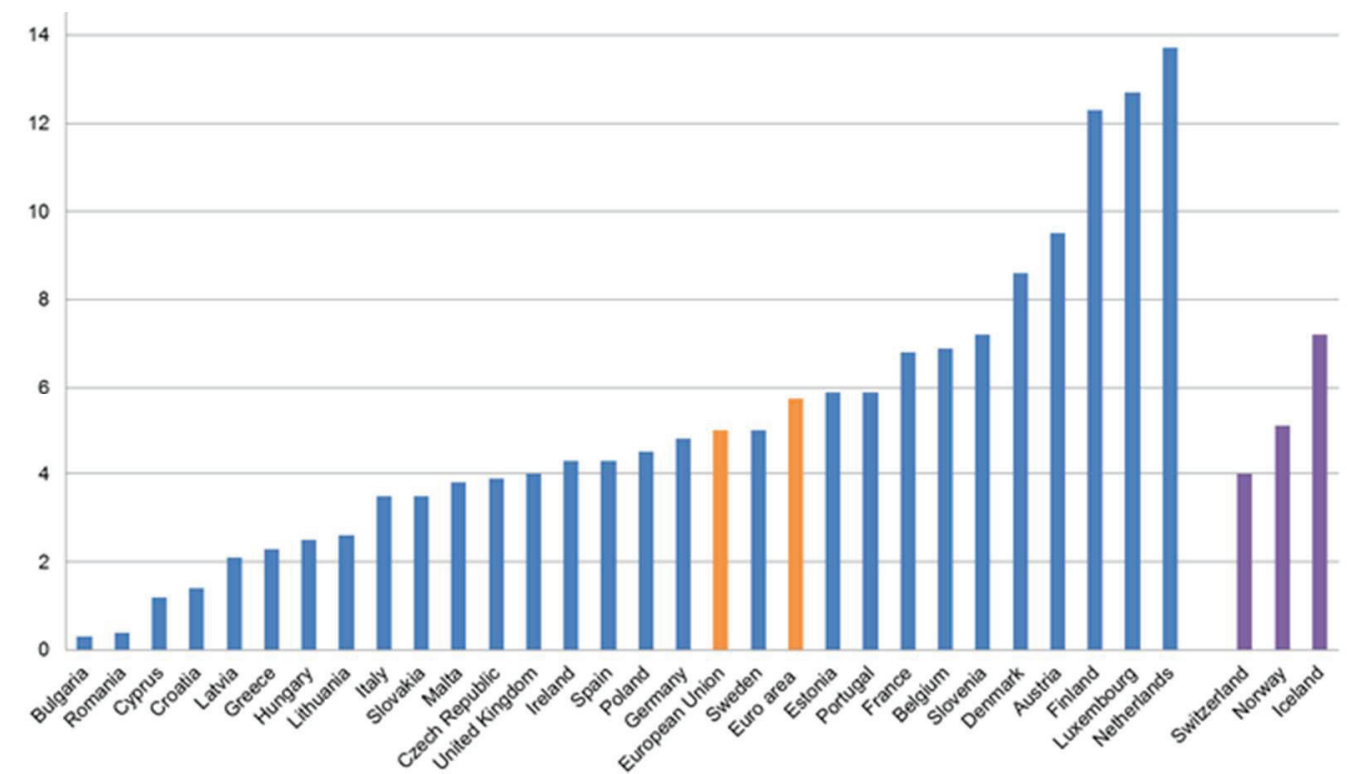

Figure 1: Employed persons aged 15-64 usually working from home in the EU (\% of total employment)

Source: https://ec.europa.eu/eurostat/web/products-eurostat-news/-/DDN-20180620-1 
Each year thousands of new tools and innovative programmes are being created with the purpose of optimising the work processes. The companies representatives have an increasingly difficult task at keeping up with the modern technologies, even more as this must match the industry in which they work and the organizational culture they represent. According to Walden University College of Management and Technology, communication through e-mail, instant messaging or even through social networks, have been among the most important influence sources of all business aspects. Technological progress brought the replace of memo or fax with emails, smartphones and tablets facilitate work outside the office, and keeping information in the cloud system rather than computers makes the information accessible everywhere and to anybody.

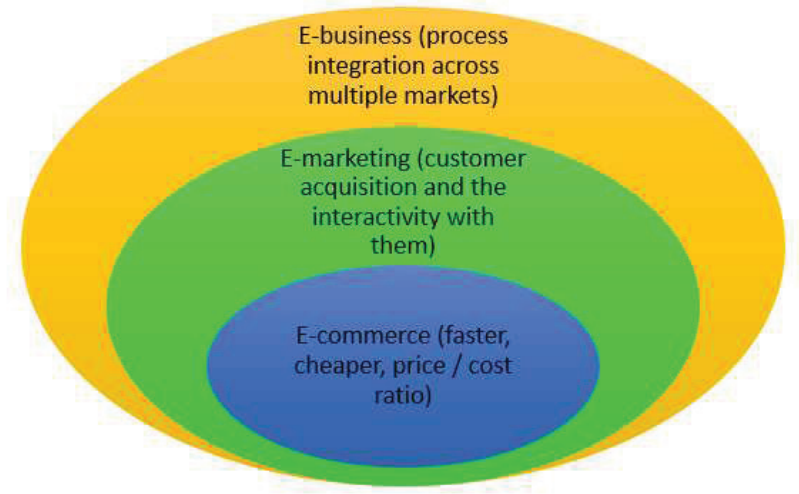

Figure 2: E-Business includes all types of electronic business

The majority of companies activities are based on digital informations, stored in computers or wireless devices and in order for them to flow from a sistem to another conectivity is necesary, which is obtained today through networks and telecommunication. The explosive development of the Internet has made communication almost instantaneous, anywhere in the world between millions of people, access to a global information base and a global market.

The companies are looking to the Internet and see its involvement in their activities as a must, with the main uses being the following [4]:

> searching and obtaining business information - a simple click allows access to milion of websites and resources for multimedia information, technical-scientific information or e-commerce;

$>$ client communication, business partners, suppliers or beneficiaries trought e-mail (electronic email exchange), discussions (attending forums, specialized discussion groups or news groups) or chat (real time text or even audio-video conversations with people all over the world, useful especially among teams that are geographically dispersed);

$>$ sale - purchase - anything can be either sold or purchased via e-commerce, provision of online services and actions;

$>$ file transfer using FTP - files that contain price lists, product and software specifications, reports, posts, images etc., all can be downloaded to the computer;

$>$ other use - telephony, videoconferencing, etc.

Practically companies get to use the Internet in business in a variety of ways ranging from company communications, collaboration, e-commerce to strategic business alliances. All this global communication between employee, clients, suppliers and other business partners is made online. Interactive websites, email, chat, discussion groups, audio and video conferences allow that all information, either company internal or external, to be searched, analysed and shared. 
"Companies need to adopt Internet technology if they do not want to risk to be left behind" say Kotler and Armstrong [1].

\section{CHANGES TO CUSTOMERS}

The key for a company success is the client, that is represented by both organisation and simple users and it is of great importance to study them in the new context. Clients are aware of the new services offered by the Internet and are becoming increasingly demanding and less patient [4]. Therefore the companies are faced with more and more pressure to become focused on the client, organized, to offer the best services and for removing those processed that add no value. The key aspect is defined here by Kotler \& Armstrong [1] as being the active and proactive adaptation, meaning those company actions to modify the offer depending on the client order, or through which the company leaves the customer to design the offer.

In favour of an efficient communication with the consumers, the virtual environment offers unprecedented possibilities for adapting products and services. In the real world, sellers specialize in highly standardized production lines and the clients try to coordinate purchases in the middle of a vast products array, based on the displayed prices. In the numeric world that easily allows the information purchase and transformation, sellers are able to adapt their offer individually, for each client. More, the virtual environment allow them to respond quickly to the reactions of these customers.

In the Anglo-Saxon space there are two terms that are used to describe the concept of offer adaptation: customization for the active adaptation and customerization for the proactive adaptation. And because in this last case the individual clients are adapting the offer themselves, we speak more and more about the notion of prosumers rather than consumers.

One might think that the term prosumer is a new one. This impression is quite wrong as the term has been around for years, especially in the marketing world. Alvin Toffler was the first to use this term in his book The Third Wave, in 1980. He defined the prosumer as "someone who blurs the distinction between a consumer and a producer" [5].

The online environment brought new meanings to this notions, prosumer being today a mix between producer and consumer. With other words, this consumer is not only using some products but gets actively involved in the production processes, influencing the companies evolution direction and their comunication strategies. 


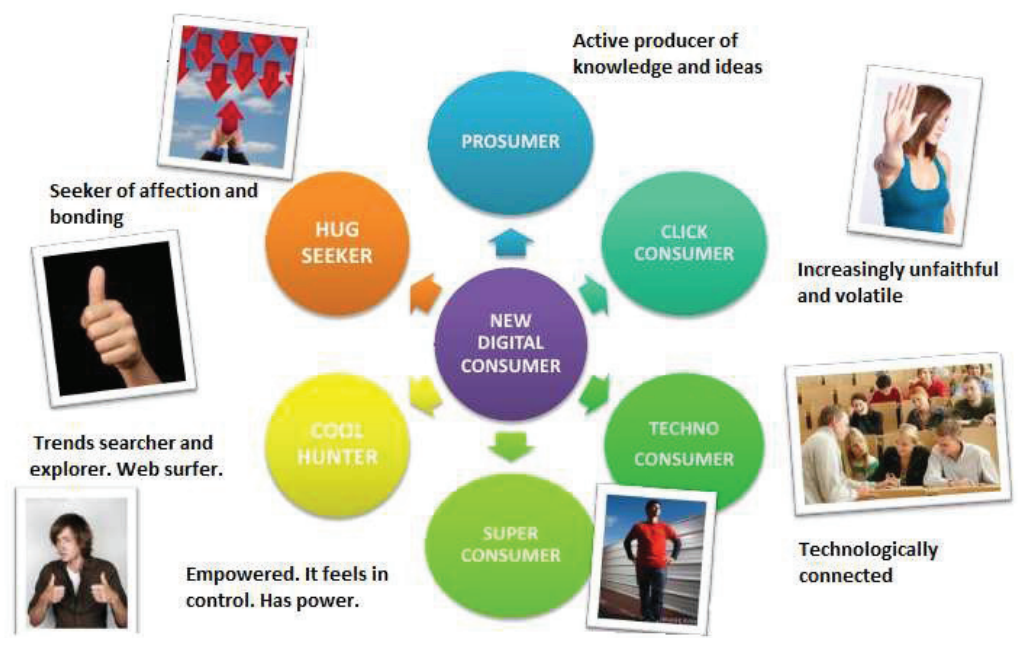

Figure 3: The new digital consumer

Source: www.consumer-insights.com.pe

Prosumer is a kind of an unsolicited company adviser, that will bluntly and publicly articulate it's opinions, whenever it feels the need to do that. Prosumer is a powerful and informed consumer that is pleased with the role of opinion leader, role that it owns and exploits to the maximum.

Prosumers are trying hardly to be part of the production process. Each time when on a website, blog or on a Facebook or Twitter account, we see user suggestions what concerns a product ingredients, the way a service works or the design of some products, we are looking at the manifestation of a prosumer. They know about themselves that are informed and feel responsible to improve the products and services they consume.

Even if prosumer as a concept is not new, its spreading is (at least in Romania). By tradition, Romanian companies were very secretive what concerns the production process. Until a few years ago it was almost impossible to create a video like "How It's Made" in one of the Romanian factories. The same was also with the concept of "Open doors days". The product fabrication and the services creation process was encrypted and shrouded in mysticism so that the user had to be satisfied with the few information that were offered.

In the meantime, things changed. The pressure coming from the customers, the need to know what they consume and the responsibility to assure that the products and services they are paying heavy money for are of quality, all this determining the companies to become more transparent and more open in the relationship with those who want to get involved.

\section{COMPETITION CHANGES}

The technology evolution help companies grow in a more rapid pace and deliver more performant services for their clients. In the same time, organizations feel the urge to develop a strategy to help them keep up to date, so that they can remain in the market, face competition and new demands from business partners.

Worldwide the classical commerce is gradually losing ground being replaced systematically and progressively by the electronic commerce in which selling, buying or exchanging goods 
and/or services, is made through Internet, by using numerous methods of payment/devices like mobile phone, wristwatch, key ring, computer etc. [6].

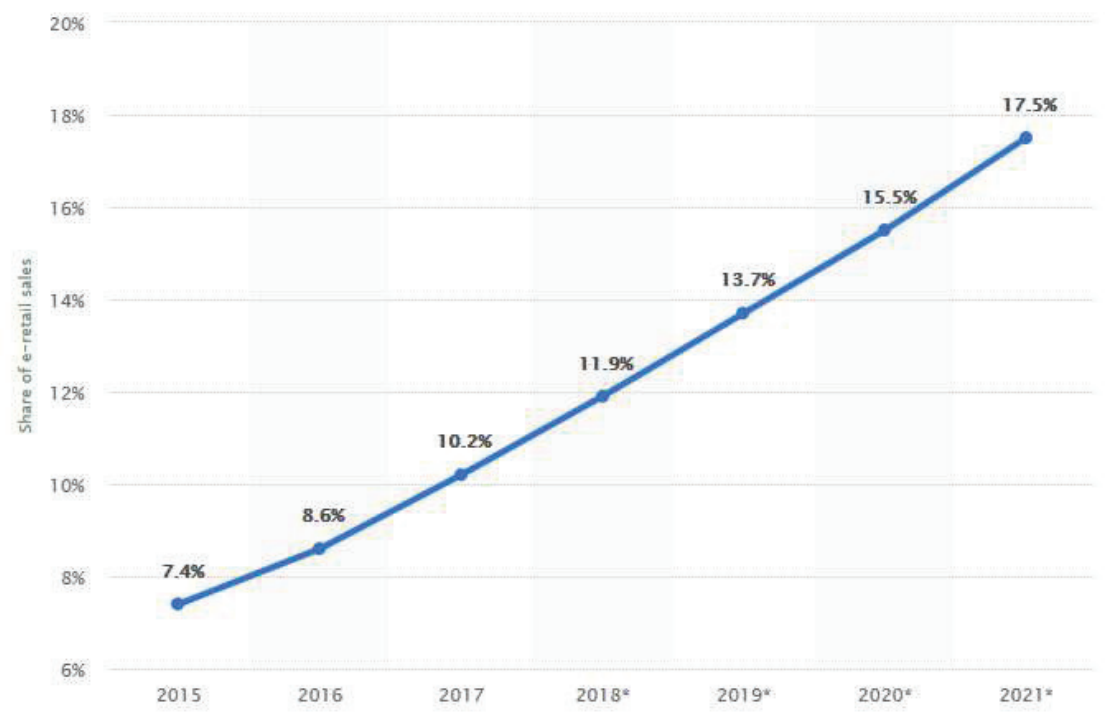

Figure 4: E-commerce share of total global retail sales from 2015 to 2021

Source: https://www.statista.com/statistics/534123/e-commerce-share-of-retail-sales-worldwide/

Company's reluctance to new technologies, the refusal to introduce the latest generation computer systems and the absence from the online environment can make it no longer being aligned with the times we live in, not to be able to cope with market demands or not to be visible for potential clients. If it does not align to the standards in which the competition is active, an organisation can lose opportunities and business partners, risking to remain isolated or even to disappear [7].

While the products digitalisation and their market growth greatly increased the competition on the vertical dimension of quality - creating markets of the "winner-takes-all" type and exacerbating the phenomenon of superstar in various areas (for example, mass media, sport, finances, corporate positions and more and more sectors such as health and university education) it also allowed the increase of competition on the horizontal quality dimension, by variety increase. While digitalization not only decreased the marginal costs of the digital products manufacturing but also the fixed costs, the progress of telecommunication made the market for digital products truly global, increasing the economic viability for an increasingly higher number of players for entering the markets for digital content, increasing a lot the available variety, to levels that were hard to imagine before the digital revolution [8].

The fact that access to Internet is so cheap allows a small business to compete with multinationals. More, the personal nature of small businesses can offer them an edge over large companies that have a more impersonal image. On the other side even if a bigger organisation can use more resources to be noticed on the Internet and to promote it's webpage, it is possible that this may not be a competitive advantage over a small business.

Looking even further, global communication can allow small business to join into consortiums and together to have sufficient resources to compete with multinationals enterprises. Small companies can increase their power on the Internet especially by forming groups. Small 
industries, such as knitting or pottery, small consulting or other professional organisation can form consortium to improve their market position.

Last but not least, online competition means analysing main competition, no matter the business scale. It is necessary to know where the potential clients are, whom they will visit when using an important search engine for the product/service they are selling. The competition analysis is crucial in optimising their own website and must follow not just identifying competition on the Internet, but also the analysis of the content and popularity of the main competition website.

Amazon and Google run daily hundreds of controlled experiments on the web interactions of their clients. As soon as an individual creates an innovation, it can be shared more easily inside an organisation or a group, using various electronic channels: emails, wikis, social media (social networks), online forums etc., which makes them potentially more useful [8].

The increasing number of goods, services and processes digitalization, accompanied by enormous access to information (often from multiple sources), quickly removes barriers. More and more markets become ,winner-takes-all” type and small quality differences between the best and the second best producer, translate in big market share differences.

On this market type, competition is based on inovation rather than price, that results in big market turbulence; beneficiaries are being quickly replaced by more successful innovators - for example Facebook vs. MySpace - in a way that resembles the „creative distruction” modell as presented by Joseph Schumpeter 60 years ago - Schumpeter J., (1942) „Capitalism, socialism and democracy".

\section{CHANGES FOR SUPPLIERS}

Internet allows access to an unlimited number of suppliers (raw materials, materials, equipment, services, labour, information, etc.) that are divided depending the way in which transactions are made like described below:

$>$ online catalogues (companies can order directly after checking out the catalogues available in websites);

$>$ vertical markets (set up in vertical business portals)

> auctions websites (there are many reverse auction websites for industrial products, where traders are displaying online their supply and invite suppliers to bid for winning the orders requests);

$>$ stock exchange markets that can be either public or private;

$>$ purchase alliances (more companies unite into a group that acts in their behalf). Suppliers and retailers are capable to collaborate on the product selling forecast, on the products flow and decisions what concerns product stock management by using collaboration networks based on the Internet [9].

The e-commerce $\mathrm{B} 2 \mathrm{~B}$ activity is referring to the commercial transactions that take place between two companies. This transactions are made through a B2B portal, that functions similar to an online shop, the main difference being that it is targeting companies rather than individuals. In a B2B portal the supplier company is presenting the products and services they offer, together with the prices, stocks and other useful details for the selling process, like customized discounts for different client types. Client company is accessing the B2B portal, is 
analysing the available offer and in case it is interested, it can place an order or an offer request depending on the situation [10].

Our world is surrounded by e-commerce market everywhere and B2B business scenario has earned itself the rightful place of being one of the most successful forms of business. Businessto-Business e-commerce is growing at a staggering pace.

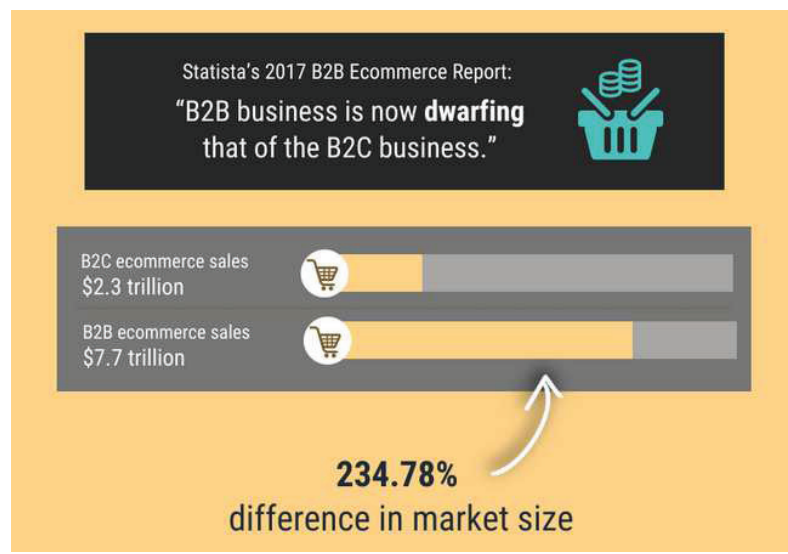

Figure 5: Global B2B Ecommerce Sales in 2017

Source: https://www.shopify.com/enterprise/global-ecommerce-statistics

By the close of 2017, B2C ecommerce sales hit $\$ 2.3$ trillion worldwide. B2B ecommerce, on the other hand, reached $\$ 7.7$ trillion. Those two data points represent a $234.78 \%$ difference in market size [11].

The dominance of B2B ecommerce means at least two things [12]:

- $\quad$ self-service is on the rise. Data from CEB Now Gartner found that "customers are 57 percent of the way through a typical purchase process prior to proactively reaching out to a supplier's sales rep." This doesn't eliminate the need for a sales staff, but it does give ecommerce a distinct advantage.

- wholesale customers - namely, independent retailers, small-to-medium franchises, and $\mathrm{B} 2 \mathrm{C}$ outlets - largely prefer a simplified ordering experience. This eliminates the need to invest your wholesale portal with all the bells and whistles of $\mathrm{B} 2 \mathrm{C}$ ecommerce.

Communication with suppliers through electronic media has the effect of decreasing the costs and time interval between order and delivery, of increasing the client satisfaction level, improvement of the goods qualities and of the services brought, birocracy reduction etc. [4]. Using the online environment in the relationship with suppliers presents also some problems, like the fact that by using the Web, many companies are looking for better suppliers, while other are complaining about the pour state of security systems.

\section{CHANGES TO INTERMEDIARIES}

Traditionally, economical transactions encompass three main participant categories: bidders, consumers and intermediaries that allow bringing together the first two categories. It is certain that the new system seriously confused this last component: the Internet can bring to the consumers and worldwide enterprises products and services with an added value much higher than those proposed by traditional intermediaries and at lower prices. It generally has repercussions on the major players on the market networks experiences, by completing or 
replacing the existing channels. In fact, it essentially expresses its disruptive effect. At the beginning of its usage as an environment for business, the Internet appeared as the perfect mean for "disintermediation" 50 . Than the dot.com era came, in which business people from all domains lived the hysteria of "getting amazoned" 51 , materialized most of the time by the traditional intermediaries removal and selling online the products and services directly towards consumers. But those that were deluded by the euphoria of the Internet disintermediation did not take into account the specific aspects of the online retail commerce, billions of dollars being invested without success in actions that had the purpose of eliminating traditional intermediaries and replacing them with online shop. In the end it proved that this move was based on naive and unrealistic expectations (the offer simply exceeded demand). The next steps: reintermediation has as representatives companies that provided services on the Internet to both consumers and organisations. In addition, companies with activities in the offline environment, developed their own online selling channels.

The typological analysis of the online intermediation act involves grouping and classification in the following models [4]:

- disintermediation: direct sale;

- intermediation itself: online brokerage, sales agents and e-tailing;

- infomediation: collecting and seling information about consumers and business;

- metamediation: organizing around an event or an important achizition.

The informational society is characterized by a significantly increased pressure at the distribution chain level, because of the apereance of new models, including: „mass" customization, decreasing product life cicle, the appearance of stocks ,just in time". Facilitating real-time relationships between participants in the distribution processes had a significant impact on it becoming more efficient, as a direct result in the decrease of the stock levels and of the market fluctuation response time [13].

\section{CHANGES IN PUBLIC INSTITUTIONS AND IN THE LARGE AUDIENCE}

World Wide Web allows any company to create a library of documents accessible to any person with Internet connection thus helping to [14]:

- Improve the company image

- Improve client oriented services

- Make commercial transactions

- New markets acquisition

- Reducing the organizational expenses

- Satisfaction of customer wishes

- Increasing the reaction speed of a company to the environment changes

- Finding new business opportunities.

In this category we refer at banks, investment firms, stock holders, interest groups, consumer associations, ecologists, public administration, public opinion, etc.

\footnotetext{
${ }^{50}$ In his book "Business@ @ the Speed of Thought" (Amaltea Publishing House, 2002), Bill Gates describes this phenomenon as follows: "Now that customers can get in touch directly with suppliers of products and services, the value added to simple transfer of goods and services is very small. Several analysts predicted the "death of the intermediary". Surely, the value of these intermediaries is approaching zero. If you are an intermediary, the promise of the Internet to offer cheaper prices and quicker services can "disintermediate" you, eliminating your role of assisting in the transaction between producer and consumer."

${ }^{51}$ Amazon was the company that launched the idea that the Internet would be the most effective way to do retail commerce.
} 
According to Digital in 2018 in Eastern Europe Report, made by We Are Social and Hootsuite, $61 \%$ of the population aged $15+$ has a bank account and only $12 \%$ has a credit card.

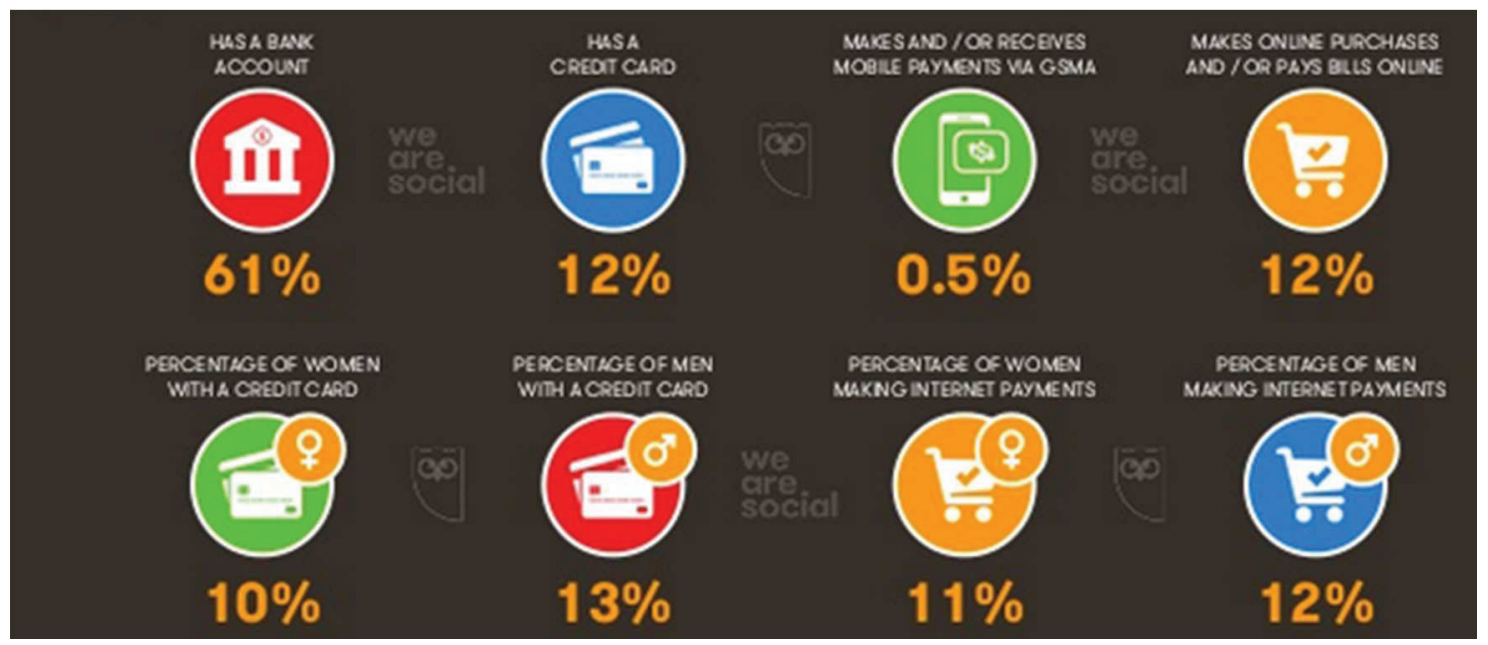

Figure 6: Financial inclusion factors in Romania in 2018

The percentage of individuals using Internet banking in Romania in 2016 was only of 5\%, which places the country at the end of the European list [15].

\begin{tabular}{ccccccccc}
\hline Country & Norway & Denmark & Finland & Netherlands & Sweden & Estonia & UK & Romania \\
\hline $\begin{array}{c}\text { Internet } \\
\text { banking } \\
\text { users }\end{array}$ & $91 \%$ & $88 \%$ & $86 \%$ & $85 \%$ & $83^{\mathrm{b}} \%$ & $79 \%$ & $64 \%$ & $5 \%$ \\
\hline
\end{tabular}

Figure 7: Individuals using the Internet for Internet banking in 2016

In Romania, even if the financial world is young, it is strong. Almost all banks have well developed and up to date websites, the vast majority offer to their clients a series of online services like: contact methods using e-mail or forms, account accessibility 24 hours/day, online assistance, online payment tools (Internet banking), virtual cards, etc.

On the other hand, public can be as much a support as an obstacle in the path of the company interests. In the online environment, the most dangerous characteristic of today web surfer is its tendency to express dissatisfaction in the discussion forums. Very demanding when talking about the way online services are done or on the quality of the purchased goods, the web surfers do not hesitate to express their critics when they are contracted or disappointed. The vast majority of the companies with Web presence are interested to detect such opinions and take them into account, also take necessary actions for fixing the situation, especially in order not to lose their existing clients and for keeping serious chances in further attracting other consumer into their virtual space. A proof is the fact that there is an increased talk about the relational digital marketing, a concept that consist in creating a strong and long term relationship with the virtual consumer.

Related to this, on the Internet there are different associations, clubs, societies, organisations or other internet surfers groups of diverse nature that plead for the fundamental rights of consumers in the online environment. 


\section{CONCLUSIONS}

In an era when connecting people to information had become a necessity, electronic commerce is a challenge. The development of the information and communication technologies allows commercial transaction to be made in a very short time and without intermediaries. Electronic commerce allow consumers to freely access the information they need and to become the owners of the desired goods in a matter of seconds.

Almost any person, company, private or public organisation was affected by the digital revolution. Internet transaction surpass all boundaries (geographic, location, culture, language, political, birocratic or legislative), determining the change of the business rules.

Today, people are increasingly busy and do not have the time required to satisfy their wishes in a direct way, because this would mean a waste of time they cannot afford. With so much available technology, men is trying to digitalize even routine activities in order not to lose a few hours in solving certain platitudes. That is why, today we prefer to sit in front of the computer and reach the virtual shop shelves to supply us with both products that are not in a traditional shop but also with common products or daily needs products.

In the Internet era, transactions are becoming more often initiated and controlled by consumers, that show a special interest to the information provided by the traders, having the tendency to react negatively at messages that only have the sole purpose to sell.

\section{REFERENCES}

[1] Kotler, Ph., Armstrong, G. (2008) Principiile marketingului, Editura Teora, București

[2] Kotler, Ph., Keller, K. L. (2006) Marketing Management, 12/E. Prentice Hall

[3] Platforme informatice pentru producție și servicii / Comerț electronic - retrived from: https://docs.google.com/viewer? $\mathrm{a}=\mathrm{v} \&$ pid=sites\&srcid=ZGVmYXVsdGRvbWFpbnxiZ XNpeHR3b2ZvdXJ8Z3g6MzUzOTg1OTQ3ZmU0MTc3OQ

[4] Stepan, A. (2009) Sisteme informatice în management și neteconomie, Universitatea Creștină „Dimitrie Cantemir” din București, 2009, pg. 214

[5] Bujor A., Avasilcai, S. (2016) Co-creation in Romanian consumer goods industry, Annals of the University of Oradea, Fascicle of Management and Technological Engineering, ISSUE \#2, AUGUST 2016, pp. 5

[6] Leţia, A. (2014) Provocările mediului digital de afaceri, International Conference of the Institute for Business Administration in Bucharest, pp. 118

[7] BIA - Business Intelligence Alliance (2016) Adaptarea la noile tehnologii: De ce este important să ținem pasul cu vremurile, retrived from: http://www.bia.ro/articol/437/adaptarea-la-noile-tehnologii-de-ce-este-important-satinem-pasul-cu-vremurile/

[8] Duhăneanu, M., Marin, F. (2014) Agenda digitală pentru Europa - riscuri și oportunități intr-o economie digitală, International Conference of the Institute for Business Administration in Bucharest, pp. 72

[9] Oprescu, G., Eleodor, D. (2014) Impactul dezvoltării economiei digitale asupra concurenţei, International Conference of the Institute for Business Administration in Bucharest, 2014, pp. 23

[10] https://www.seniorsoftware.ro/e-commerce/ce-inseamna-e-commerce-b2b/

[11] https://www.statista.com

[12] https://www.shopify.com/enterprise/global-ecommerce-statistics 
[13] Academia de Studii Economice, Catedra de Marketing - Cybermarketing - Mixul de marketing in mediul online, retrived from: http://orzanm.ase.ro/cybermarketing/pdf/mko6.pdf

[14] Neault, E. (2006) Web Marketing, Editura Fundaţiei „România de Mâine”, Bucureşti

[15] Kiss, M. (2017) Study on the evolution and use of internet banking services in Romania, Annals of the „Constantin Brâncuşi” University of Târgu Jiu, Economy Series, Issue 6/2017, pp. 84

[16] Digital in 2018 in Eastern Europe Report, made by We Are Social and Hootsuite, retrieved from: https://www.slideshare.net/wearesocial/digital-in-2018-in-easterneurope-part-2-east-86865266 